\title{
Dynamics of Linear Hydraulic Cylinder with Mass Load
}

Adam Bureček, Lumír Hružík, Martin Vašina

Faculty of Mechanical Engineering, VSB-Technical University of Ostrava. 17. listopadu 15/2172, 70833 Ostrava-Poruba. Czech Republic. E-mail: adam.burecek@vsb.cz, lumir.hruzik@vsb.cz, martin.vasina@vsb.cz

The paper deals with examination of dynamics of linear hydraulic cylinder with mass load. The hydraulic cylinder is placed in vertical position. There is experimentally simulated a system state. In this case a higher piston velocity is achieved due to the mass load compared to the piston velocity that corresponds to a supplied flow. A piston oscillation of the hydraulic cylinder is caused by rapid stop of movement in a desired position. There are experimentally evaluated eigenfrequencies of the linear hydraulic cylinder depending on the piston position and the mass load. Mineral oil was used as the working liquid. Time dependencies of pressures are measured on sides of the piston and the piston rod. Furthermore there are measured time dependencies of the piston position and the oil temperature. A mathematical model is created for this hydraulic system. This model is realized by Matlab SimHydraulics software. There are simulated time dependencies of the piston position and the pressure on the side of the piston rod. The mathematically simulated time dependencies of the pressure and the piston position are compared with the experiment.

Keywords: Eigenfrequency, Hydraulic Cylinder, Simulation, Measurement, Piston Position.

\section{Acknowledgements}

The work presented in this paper was supported by a grant SGS „Research in field of fluid systems dynamics“ SP2017/103.

\section{References}

[1] ̌EHǑ̌, J., FULEMOVÁ, L., RUT, D., TříSKOVÁ, V., KUTLWAŠER, J., KOUŘIL, K. (2015). Reaming of Very Precise Holes in Hydrostatic Component. In: Manufacturing Technology. 2015, Vol. 15, No. 3, pp. 409-415. JEPU in Usti nad Labem. Czech Republic.

[2] SEDLÁK, J., SLANÝ, M., FIALA, Z., JAROŠ, A., BLAŽKOVÁ, V. (2015). Testing of Implant Prototype of Femoral Component Using Hydraulic Machine ZD40. In: Manufacturing Technology. 2015, Vol. 15, No. 3, pp. 416-423. JEPU in Usti nad Labem. Czech Republic.

[3] BEATER, P. (1999). Entwurf Hydraulischer Maschinen: Modellbildung, Stabilitätsanalyse und Simulation Hydrostatischer Antriebe und Steuerungen. pp. 259. Springer. Berlin.

[4] HRUŽÍK, L., VAŠINA, M., BUREČEK, A. (2013). Evaluation of Bulk Modulus of Oil System with Hydraulic Line. In: EPJ Web of Conferences 2013, Vol. 45, article No. 01041. Polypress s.r.o. in Liberec. Czech Republic.

[5] HRUŽÍK, L., BUREČEK, A., VAŠINA, M., BÍLEK, O. (2015). Non-Destructive Experimental Method for Determination of Modulus of Elasticity of Hydraulic Hoses In: Manufacturing Technology. 2015, Vol. 15, No. 3, pp. 344-350. JEPU in Usti nad Labem. Czech Republic.

[6] BUREČEK, A., HRUŽÍK, L., VAŠINA, M. (2015). Determination of Undissolved Air Content in Oil by Means of a Compression Method. In: Strojniski vestnik - Journal of Mechanical Engineering, Vol. 61, No. 7-8, pp. 477485. Grafex in Ljubljana. Slovenia.

[7] JABLONSKÁ, J. (2014). Compressibility of the fluid. In: EPJ Web of Conferences 2014, Vol. 67, article No. 02048. Polypress s.r.o. in Liberec. Czech Republic.

[8] ŽMINDÁK, M., MEŠKO, J., PELAGIC, Z., ZRAK, A. (2014). Finite element analysis of crack growth in pipelines. In: Manufacturing Technology. 2014, Vol. 14, No. 1, pp. 116-122. JEPU in Usti nad Labem. Czech Republic.

[9] BUREČEK, A., HRUŽÍK, L., VAŠINA, M. (2013). Simulation of Dynamics of System with Hydraulic Lines and Linear Hydraulic Motor with Mass Load. In: EPJ Web of Conferences 2013, Vol. 45, article No. 010017. Polypress s.r.o. in Liberec. Czech Republic.

[10] JIROUŠ, S., FRAŇA, K. (2015). Pressure Analysis on the Surface Gearing Investigated by Numerical Simulation of Oil Flow in the Tooth Wheel Gap. In: Manufacturing Technology. 2015, Vol. 15, No. 5, pp. 850-853. JEPU in Usti nad Labem. Czech Republic. 